\title{
AN ASSESSMENT OF SEASONALITY EFFECT IN SECTORAL INDICES
}

\author{
K. Rajasekar \\ Ph.D. Research Scholar, Bharathidasan School of Management, Bharathidasan University, \\ Tiruchirappalli, Tamil Nadu, India

\section{Dr. M. Babu} \\ Associate Professor, Bharathidasan School of Management, Bharathidasan University, \\ Tiruchirappalli, Tamil Nadu, India

\section{Dr. C. Hariharan} \\ Assistant Professor, Department of Business Administration, Nehru Arts and Science College \\ (Autonomous), Coimbatore, 'Tamil Nadu, India
}

\begin{abstract}
Any new information about the economy is transmitted fast and it may influence the financial markets, positively or negatively. The present study used Descriptive Statistics and Regression Model, to investigate the April month effect on Indian financial sector indices, namely, Nifty Bank Index, Nifty Financial Services Index, Nifty PSU Index and Nifty Private Bank Index of NSE India Ltd. The results of Descriptive Statistics and Regression Model found that April month of every financial year, affected the daily prices of Indian financial sector indices, namely, Nifty bank Index, Nifty Financial Services, Nifty PSU and Private Bank Sector indices, during the study period. Finally, the study concluded that April month of every financial year may be affecting the Indian stock markets. Investors may concentrate more for their investments Hence April of every financial year.
\end{abstract}

Key words: NSE, April month Effect, Stock Market

Cite this Article: K. Rajasekar, M. Babu and C. Hariharan, An Assessment of Seasonality Effect in Sectoral Indices, International Journal of Management, 11(12), 2020, pp 2128-2136.

http://iaeme.com/Home/issue/IJM?Volume=11\&Issue=12

\section{INTRODUCTION}

Seasonality refers to regular and repetitive fluctuation, in a time series, which occurs periodically over a span of less than a year. The main cause of seasonal variations, in time series data, is the change in climate. For example, sales of woolen clothes generally increase 
in winter season. Besides, customs and tradition also affect economic variables, for instance, sales of gold increase during marriage seasons. Similarly, stock returns exhibit systematic patterns at certain times of the day, week or month. The most common of these are Monthly Patterns. Certain months provide better returns as compared to others i.e. the Month of the Year Effect. The existence of seasonality in stock returns, however, violates an important hypothesis in finance called the Efficient Market Hypothesis (EMH). The Efficient Market Hypothesis is a central paradigm in finance.

Commonly referred to as the "April Effect", "Turn-Of-The- Financial Year" effect is the tendency of the stock market to rise between the last day of the last financial month and the end of the first week of the first month of the next financial year. In many developed countries, financial year starts in April and ends in March, which is the reason behind the common nomenclature of this anomaly as the April Effect. Returns are high in small firm stocks, which might have experienced negativity in the immediate past and these small stocks tend to outperform large stocks during the course of the first month of the year (Rashmita Sahoo (2018), Eric Girardin and Fatemeh Salimi Namin (2019), Fahad Ali and Numan Ulku (2020) ).1 This is the reason why this effect is predominantly noticeable in stock indices having higher proportion of small firm listings.. A 'positive April returns' means that the market is on the road for a gainful year, and a 'negative April returns' indicate weakness in the market through the following March (Cooper et.al.,2006).

In order to recognize study limitations and understand methodologies used in the areas of calendar anomalies, a short overview is given here. The effect of December months in the Indian stock market was investigated using Generalized Auto Regressive Conditional Heteroscedasticity (2009) and Gupta (2007). Garima (2017). The findings verified the effects on the Indian stock market of December month. The Day of the Week ended the presence of Rashmita Sahoo in the Indian stock exchange in 2018. The effect of the month day was evaluated at Indian stock market with Harshita, Shveta Singh (2019), Surendra S. Yadav, the results of the analysis indicate that the seasonal effect on the stock exchange in the form of April/May. The study of the impact of the Week Day on the Indian stock exchange by Tripathy Amit, Leepsa N.M (2018) shows that no day of monthly effect, i.e., the effect on Monday and Friday effect on Indian stock market, was observes. The January month effect in Brazilian equity market was tested by Grossi, J. C., \& Malaquias, R. F. (2019). Using panel data regression model, the study confirmed that January month effect was presence in the Brazilian equity market. Using EGARCH Model, Kayacetin, V., \& Lekpek, S. (2016) confirmed that existence of turn of the month effect in Turkish Equity market. Tarika Singh Sikarwar, Karuna Shrivastava and Pratibha Jadon (2020) tested the Friday effect in Indian stock market and the fings of the study showed that there was Friday effect presence in Indian stock market. Using OLS regression, Singh, S., \& Das, C. (2020) studied the calendar anomalies in Indian services sector indices. The findings of this analysis revealed that the effects on stock indexes was January monthly and annual. Sadia Anjum (2020) examined the effects on Pakistan's stock market day, weekend effect and January effect. The research used multiple regressions, and it was determined that in Pakistan the above calendar effects occurred. The calendar effects in the stocks in Vietnam were evaluated in Pham Dan Khanh and Pham Thanh Dat (2020) and it was shown the Monetary Impact in the stock market in Vietnam. The impact in Chinese stock market on Monday, Fahad Ali and Numan Ulku (2020) discovered. The impact on the foreign exchange market of January months was examine by Eric Girardin and Fatemeh Salimi Namin (2019) and verified that the exchange rate was effective on January's month. The fact that the days of the month and month of the year occur in the crude petroleum returns in Brent and WTI is seen by Sobia Quayyoum, Mushtaq Hussain Khan, Syed Zulfiqar Ali Shah, Biagio Simonetti, and Michela Matarazzo (2019). 
Shaista Wasuzzamán (2017) found that the pilgrimage of Hajj had an effect on the stock market in Saudi Arabian using the ARMA(p,q)-GARCH(1,1) model.

\section{AIM AND OBJECTIVES OF THE STUDY}

The goal of this analysis was to investigate whether Indian stock markets had an annual impact on the month. The following objectives were formulated for the research.

- To test the normality of daily prices of sample Indian financial sector indices, during the study period.

- To examine the April month effect on daily prices of sample Indian financial sector indices, during the study period.

\section{HYPOTHESES}

The study tested the following hypotheses, for the purpose of testing the objectives.

NH $_{01}$ : The monthly prices of sample Indian Financial Sector indices are not normally distributed during the study period.

$\mathbf{N H}_{\mathbf{0 2}}$ : There is no April month effect on sample Indian Financial Sector indices during the study period.

\section{METHODOLOGY OF THE STUDY}

\section{Sample Selection}

For the purpose of this study, NIFTY BANK, FINANCIAL SERVICES, PRIVATE BANK and PSU BANK NSE Sectoral Indices considered to study the Stock Market in India.

\section{Sources of Data}

The study used daily closing prices of sample Indian Financial Sector Indices, collected from official website of National Stock Exchanges of India. The other required data were collected from various books, journals and research data bases.

\section{Period of the Study}

This research has spanned 10 years, from 1.4.2009 to 31.03. 2019.

\section{Tools Used for the Analysis}

The present study used the following statistical tools, for analyzing the impact of economic events, on Indian stock market.

1. Descriptive Statistics

2. Regression Model

\section{RESULTS AND DISCUSSION}

\subsection{Nifty Bank Index}

Table 1 presents Monthly wise regular returns for the Nifty Bank Index descriptive statistical data. Table 1 indicates that in April the highest average return was obtained (0.008145). It should be noted that mean returns are reported in all months. Therefore, during these months, buyers usually sell the scripts. 
Table 1 Results of Descriptive Statistics for NSE Nifty Bank Index

\begin{tabular}{|l|l|l|l|l|l|}
\hline & \multicolumn{1}{|c|}{ Mean } & \multicolumn{1}{c|}{ Std. Dev. } & \multicolumn{1}{c|}{ Skewness } & \multicolumn{1}{c|}{ Kurtosis } & \multicolumn{1}{c|}{$\begin{array}{c}\text { Jarque- } \\
\text { Bera }\end{array}$} \\
\hline APRIL & 0.008145 & 0.049956 & 5.684223 & 47.12534 & 15918.2 \\
\hline MAY & 0.006499 & 0.040037 & 3.603287 & 21.79504 & 3612.929 \\
\hline JUNE & 0.005136 & 0.039105 & 2.702763 & 23.2954 & 3914.965 \\
\hline JULY & 0.005232 & 0.036509 & 5.476368 & 44.48992 & 16725.83 \\
\hline AUGUST & 0.005078 & 0.043195 & 5.930614 & 47.2993 & 18227.02 \\
\hline SEPTEMBER & 0.004717 & 0.049097 & 1.603191 & 34.39175 & 8380.667 \\
\hline OCTOBER & 0.004136 & 0.045379 & 0.747631 & 37.26582 & 9754.169 \\
\hline NOVEMBER & 0.004593 & 0.046795 & 4.192652 & 33.05051 & 8111.22 \\
\hline DECEMBER & 0.003499 & 0.052533 & 3.178852 & 35.87588 & 9810.882 \\
\hline JANUARY & 0.003514 & 0.052551 & 2.911177 & 40.24498 & 12612.16 \\
\hline FEBRUARY & 0.003977 & 0.05357 & 3.853832 & 39.17221 & 11227.66 \\
\hline MARCH & 0.004967 & 0.042293 & 2.614012 & 38.77516 & 11165.62 \\
\hline
\end{tabular}

Source: $w w w . n s e i n d i a . c o m$

During the months of January and July, respectively, the highest standard default $(0.052551)$ and lowest standard default (0.036509) were registered. This indicates that in January the market was very volatile and in July low volatility was found. Until buying, investors should be aware of the volatility. For all months, the regular return was positive. All months of the year leptokurtic was discovered, and in August the greatest value (47.2993) was discovered. Jarque-Bera values reflect the distribution of the data normally.

Table 2 Results of Regression Analysis for NSE Nifty Bank Index

\begin{tabular}{|c|c|c|c|c|}
\hline Month & Coefficient & Std. Error & t-Statistic & Prob. \\
\hline MAY & -0.04153 & 0.086545 & -0.47981 & 0.632 \\
\hline JUNE & 0.018575 & 0.091246 & 0.203572 & 0.8389 \\
\hline JULY & 0.323438 & 0.092626 & 3.491883 & 0.0006 \\
\hline AUGUST & -0.05945 & 0.102701 & -0.57889 & 0.5634 \\
\hline SEPTEMBER & 0.035408 & 0.09181 & 0.385671 & 0.7002 \\
\hline OCTOBER & -0.00812 & 0.118611 & -0.0685 & 0.9455 \\
\hline NOVEMBER & -0.07454 & 0.090587 & -0.82284 & 0.4117 \\
\hline DECEMBER & -0.06372 & 0.084127 & -0.75743 & 0.4498 \\
\hline JANUARY & -0.00748 & 0.066212 & -0.1129 & 0.9102 \\
\hline FEBRUARY & 0.014481 & 0.071926 & 0.201327 & 0.8407 \\
\hline MARCH & 0.201345 & 0.100773 & 1.998012 & 0.0473 \\
\hline $\mathrm{C}$ & 0.007452 & 0.004869 & 1.530635 & 0.1277 \\
\hline DUMMY & -0.00251 & 0.007413 & -0.3386 & 0.7353 \\
\hline R-squared & 0.09525 & \multicolumn{2}{|c|}{ Mean dependent var } & 0.008145 \\
\hline Adjusted R-squared & 0.031759 & \multicolumn{2}{|c|}{ S.D. dependent var } & 0.049956 \\
\hline S.E. of regression & 0.049156 & \multicolumn{2}{|c|}{ Akaike info criterion } & -3.11961 \\
\hline Sum squared resid & 0.413187 & \multicolumn{2}{|c|}{ Schwarz criterion } & -2.89247 \\
\hline Log likelihood & 300.0041 & \multicolumn{2}{|c|}{ Hannan-Quinn criter. } & -3.02755 \\
\hline F-statistic & 1.500208 & \multicolumn{2}{|c|}{ Durbin-Watson stat } & 1.897441 \\
\hline Prob(F-statistic) & 0.128071 & & & \\
\hline
\end{tabular}

Source: www.nseindia.com

The results of the regression analysis for Nifty Bank Index are presented in Table- 2 . The analysis shows that negative coefficient value was employed in the months of May, August, October, November, December, and January while the positive value was noted in remaining months. The highest coefficient values was found in July and March at significant of 5\% level. it confirmed that there was no difference in sample months return. Hence, the null hypothesis is accepted, because it did not confirm the anomalies in Nifty Bank Index, during the study period. 


\subsection{Nifty Financial Services Index}

Table 3 Results of Descriptive Statistics for NSE Nifty Financial Services Index

\begin{tabular}{|l|c|c|c|c|c|}
\hline & Mean & Std. Dev. & Skewness & Kurtosis & $\begin{array}{c}\text { Jarque- } \\
\text { Bera }\end{array}$ \\
\hline APRIL & 0.008281 & 0.04998 & 5.689307 & 44.81492 & 14397.7 \\
\hline MAY & 0.006551 & 0.039438 & 3.662733 & 21.8933 & 3661.355 \\
\hline JUNE & 0.005352 & 0.03676 & 3.105232 & 22.57476 & 3742.952 \\
\hline JULY & 0.005493 & 0.03466 & 5.130527 & 39.82622 & 13274.92 \\
\hline AUGUST & 0.005265 & 0.041806 & 5.609174 & 43.07017 & 14861.78 \\
\hline SEPTEMBER & 0.00492 & 0.046263 & 1.87527 & 31.94938 & 7172.122 \\
\hline OCTOBER & 0.004432 & 0.043634 & 1.48033 & 37.40986 & 9890.333 \\
\hline NOVEMBER & 0.005013 & 0.044583 & 4.512685 & 32.76438 & 8061.464 \\
\hline DECEMBER & 0.00396 & 0.049331 & 3.580535 & 36.02178 & 9990.041 \\
\hline JANUARY & 0.003987 & 0.047493 & 4.07818 & 39.40256 & 12351.1 \\
\hline FEBRUARY & 0.004467 & 0.050124 & 4.300427 & 39.36666 & 11463.01 \\
\hline MARCH & 0.005197 & 0.041029 & 2.775283 & 39.34814 & 11548.3 \\
\hline
\end{tabular}

The results of the Month-wise daily Financial Services Index descriptive statistics are presented in Table 3. The study shows that in April there was the highest average return $(0.008281)$.

The highest value (0.050124) and the least value (0.03466) of standard deviation were noticed in February and July. The result showed that the market was highly volatile in January and minimum volatile in July. The month wise return was positively skewed for the all months. The return distribution was leptokurtic and it was the highest (44.81492) in April. Jarque- Bera test indicates that the series were normally distributed.

Table 4 Results of Regression Analysis for NSE Nifty Financial Services Index

\begin{tabular}{|c|c|c|c|c|}
\hline Month & Coefficient & Std. Error & t-Statistic & Prob. \\
\hline MAY & -0.03446 & 0.088601 & -0.38898 & 0.6978 \\
\hline JUNE & 0.032609 & 0.097767 & 0.33354 & 0.7391 \\
\hline JULY & 0.331165 & 0.097874 & 3.383585 & 0.0009 \\
\hline AUGUST & 0.030831 & 0.086345 & 0.357066 & 0.7215 \\
\hline SEPTEMBER & 0.080298 & 0.098991 & 0.811162 & 0.4184 \\
\hline OCTOBER & -0.05449 & 0.125961 & -0.43258 & 0.6659 \\
\hline NOVEMBER & -0.06789 & 0.095282 & -0.71253 & 0.4771 \\
\hline DECEMBER & -0.09477 & 0.080424 & -1.1784 & 0.2403 \\
\hline JANUARY & -0.01233 & 0.07503 & -0.16434 & 0.8697 \\
\hline FEBRUARY & 0.023936 & 0.078053 & 0.306667 & 0.7595 \\
\hline MARCH & 0.202161 & 0.098197 & 2.058731 & 0.041 \\
\hline $\mathrm{C}$ & 0.006805 & 0.004904 & 1.387712 & 0.167 \\
\hline DUMMY & -0.00222 & 0.007411 & -0.29944 & 0.765 \\
\hline R-squared & 0.0957 & \multicolumn{2}{|c|}{ Mean dependent var } & 0.008281 \\
\hline Adjusted R-squared & 0.032241 & \multicolumn{2}{|c|}{ S.D. dependent var } & 0.04998 \\
\hline S.E. of regression & 0.049168 & \multicolumn{2}{|c|}{ Akaike info criterion } & -3.11913 \\
\hline Sum squared resid & 0.413385 & \multicolumn{2}{|c|}{ Schwarz criterion } & -2.89199 \\
\hline Log likelihood & 299.9599 & \multicolumn{2}{|c|}{ Hannan-Quinn criter. } & -3.02707 \\
\hline F-statistic & 1.508048 & \multicolumn{2}{|c|}{ Durbin-Watson stat } & 1.927077 \\
\hline Prob(F-statistic) & 0.125204 & & & \\
\hline
\end{tabular}

Source: www.nseindia.com

The findings of the financial services index regression study are seen in Table 4. In May, October, November, December, January, the effects were found to be negative and for the remaining months a positive coefficient was obtained. The July and March coefficients were 
high and statistically relevant at a risk level of 5 per cent. In the analysis, all of the coefficients were trivial. R squared was 0.0957. Durbin-Watson statistic was smaller than 2, and the residuals revealed a serial correlation. It showed plainly that the monthly returns had little difference. This means that the zero explanation is acknowledged because the Financial Services Index does not validate the monthly anomalies.

\subsection{Nifty Private Bank Index}

Table 5 Results of Descriptive Statistics for NSE Nifty Private Bank Index

\begin{tabular}{|l|c|c|c|c|c|}
\hline & Mean & Std. Dev. & Skewness & Kurtosis & Jarque-Bera \\
\hline APRIL & 0.010329 & 0.05362 & 6.340965 & 51.90948 & 19572.76 \\
\hline MAY & 0.008182 & 0.043016 & 4.528695 & 28.43969 & 6502.159 \\
\hline JUNE & 0.006885 & 0.041734 & 4.119961 & 23.86956 & 4467.983 \\
\hline JULY & 0.006727 & 0.040292 & 5.272525 & 37.76714 & 11989.57 \\
\hline AUGUST & 0.00664 & 0.046208 & 5.448743 & 40.68936 & 13340.11 \\
\hline SEPTEMBER & 0.006354 & 0.047393 & 3.692703 & 33.73954 & 8412.153 \\
\hline OCTOBER & 0.005994 & 0.043395 & 3.821362 & 37.24943 & 10210.65 \\
\hline NOVEMBER & 0.006453 & 0.047139 & 5.624182 & 38.14223 & 11345.85 \\
\hline DECEMBER & 0.005206 & 0.051237 & 5.341447 & 40.74587 & 13465.15 \\
\hline JANUARY & 0.005356 & 0.049657 & 5.290046 & 45.67555 & 17156.63 \\
\hline FEBRUARY & 0.005715 & 0.053327 & 4.880182 & 42.35578 & 13495.67 \\
\hline MARCH & 0.006507 & 0.042317 & 4.578087 & 47.12216 & 17344.71 \\
\hline
\end{tabular}

Source: www.nseindia.com

Table 5 shows the findings for the Private Bank Index with simple statistics. The highest average return (0.010329) was specifically shown in Table-5 in the month of April. It must be verified that positive mean returns have been reported every month.

A standard deviation was reported in February and July with the highest values $(0,05362)$ and the lowest $(0,040292)$. This found that during the month of January the market was most volatile and during the analysis period less volatile during the month of July. Until buying, investors should keep this in mind. Jarque-Bera Test revealed that the sequence was naturally distributed and was thus refused at $1 \%$ of the value.

Table 6 Results of Regression Analysis for NSE Nifty Private Bank Index

\begin{tabular}{|l|c|c|c|c|}
\hline \multicolumn{1}{|c|}{ Variable } & Coefficient & Std. Error & t-Statistic & Prob. \\
\hline MAY & -0.01953 & 0.088375 & -0.22104 & 0.8253 \\
\hline JUNE & 0.00891 & 0.091909 & 0.096939 & 0.9229 \\
\hline JULY & 0.314734 & 0.090606 & 3.473672 & 0.0007 \\
\hline AUGUST & -0.05562 & 0.106693 & -0.52126 & 0.6029 \\
\hline SEPTEMBER & 0.048983 & 0.101424 & 0.482955 & 0.6297 \\
\hline OCTOBER & -0.04641 & 0.129939 & -0.35717 & 0.7214 \\
\hline NOVEMBER & -0.06196 & 0.092249 & -0.67165 & 0.5027 \\
\hline DECEMBER & -0.06012 & 0.092839 & -0.64759 & 0.5181 \\
\hline JANUARY & -0.00691 & 0.076007 & -0.0909 & 0.9277 \\
\hline FEBRUARY & 0.01123 & 0.080305 & 0.139837 & 0.889 \\
\hline MARCH & 0.191816 & 0.106776 & 1.796443 & 0.0742 \\
\hline C & 0.009466 & 0.005369 & 1.76319 & 0.0797 \\
\hline DUMMY & -0.00333 & 0.007977 & -0.41675 & 0.6774 \\
\hline R-squared & 0.092053 & \multicolumn{2}{|c|}{ Mean dependent var } & 0.010329 \\
\hline Adjusted R-squared & 0.028337 & \multicolumn{2}{|c|}{ S.D. dependent var } & 0.05362 \\
\hline S.E. of regression & 0.052855 & \multicolumn{2}{|c|}{ Skaike info criterion } & -2.97451 \\
\hline Sum squared resid & 0.477707 & \multicolumn{2}{|c|}{ Hannan-Quinn criter. } & -2.74737 \\
\hline Log likelihood & 286.6552 & \multicolumn{2}{|c|}{ Durbin-Watson stat } & 1.942657 \\
\hline F-statistic & 1.444747 & \multicolumn{2}{|c|}{} \\
\hline Prob(F-statistic) & 0.150008 & \multicolumn{2}{|c|}{} & \\
\hline
\end{tabular}

Source: $w w w . n s e i n d i a . c o m$ 
The findings of the Private Bank Index Regression Study are seen in Table 6. The study indicates the negative coefficient value for the remaining months in May, August, October, November, December and January. The coefficients in July and March were high and statistically significant. $\mathrm{R}^{2}$ of 0.092053 is positive, and Durbin- Watson statistic value is less than two indicated serial correlation. It showed that differences are exist in the returns of different months. Hence, the null hypothesis is accepted.

\subsection{Nifty PSU Bank Index}

Table 7 Results of Descriptive Statistics for NSE Nifty PSU Bank Index

\begin{tabular}{|l|c|c|c|c|c|}
\hline & Mean & Std. Dev. & Skewness & Kurtosis & Jarque-Bera \\
\hline APRIL & 0.001009 & 0.06492 & 0.015282 & 27.38953 & 4560.517 \\
\hline MAY & 0.00044 & 0.054838 & -1.96624 & 36.32128 & 10038.13 \\
\hline JUNE & -0.00105 & 0.048744 & -0.86785 & 29.17777 & 5793.091 \\
\hline JULY & -0.00046 & 0.048484 & 0.80081 & 36.6111 & 10284.8 \\
\hline AUGUST & -0.00054 & 0.048849 & 4.813009 & 45.53093 & 16480.01 \\
\hline SEPTEMBER & -0.00217 & 0.072762 & -4.52628 & 53.32986 & 22009.95 \\
\hline OCTOBER & -0.00284 & 0.072468 & -3.57054 & 36.97125 & 9991.796 \\
\hline NOVEMBER & -0.00244 & 0.066772 & -2.00672 & 27.77313 & 5248.464 \\
\hline DECEMBER & -0.00283 & 0.06942 & -1.87497 & 30.58592 & 6781.643 \\
\hline JANUARY & -0.00334 & 0.075435 & -2.04017 & 36.60678 & 10171.33 \\
\hline FEBRUARY & -0.00397 & 0.083025 & -3.07902 & 45.83264 & 15370.57 \\
\hline MARCH & -0.00174 & 0.068136 & -4.53167 & 47.69 & 17761.03 \\
\hline
\end{tabular}

Source: www.nseindia.com

Table 7 explains the summary of descriptive statistics, for PSU Bank Index. The results noticed that the highest mean value (0.001009) in April. It confirmed that all the months registered negative mean returns.

Standard deviation was reported at the maximum value $(0.083025)$ in February. This has demonstrated high volatility during February and low volatility during the sample cycle in the month of July.

Table 8 Results of Regression Analysis for NSE Nifty PSU Bank Index

\begin{tabular}{|l|c|c|c|c|}
\hline \multicolumn{1}{|c|}{ Variable } & Coefficient & Std. Error & t-Statistic & Prob. \\
\hline MAY & 0.061085 & 0.089277 & 0.684222 & 0.4948 \\
\hline JUNE & -0.04067 & 0.098185 & -0.41417 & 0.6793 \\
\hline JULY & 0.136087 & 0.107431 & 1.266736 & 0.207 \\
\hline AUGUST & 0.01549 & 0.112032 & 0.138265 & 0.8902 \\
\hline SEPTEMBER & -0.03038 & 0.073792 & -0.41175 & 0.681 \\
\hline OCTOBER & 0.010537 & 0.085394 & 0.123393 & 0.9019 \\
\hline NOVEMBER & -0.00369 & 0.090463 & -0.04083 & 0.9675 \\
\hline DECEMBER & -0.04363 & 0.088043 & -0.49556 & 0.6208 \\
\hline JANUARY & 0.008083 & 0.063778 & 0.12673 & 0.8993 \\
\hline FEBRUARY & -0.01267 & 0.061137 & -0.20728 & 0.836 \\
\hline MARCH & 0.071219 & 0.080279 & 0.887142 & 0.3762 \\
\hline C & 0.003956 & 0.006408 & 0.617425 & 0.5378 \\
\hline DUMMY & -0.00744 & 0.010006 & -0.74311 & 0.4584 \\
\hline R-squared & 0.021565 & \multicolumn{2}{|c|}{ Mean dependent var } & 0.001009 \\
\hline Adjusted R-squared & -0.0471 & \multicolumn{2}{|c|}{ S.D. dependent var } & 0.06492 \\
\hline S.E. of regression & 0.066431 & \multicolumn{2}{|c|}{ Akaike info criterion } & -2.51727 \\
\hline Sum squared resid & 0.754637 & \multicolumn{2}{|c|}{ Schwarz criterion } & -2.29013 \\
\hline Log likelihood & 244.5891 & \multicolumn{2}{|c|}{ Dannan-Quinn criter. } & -2.42521 \\
\hline F-statistic & 0.314068 & \multicolumn{2}{|c|}{ Durbin-Watson stat } & 1.902257 \\
\hline Prob(F-statistic) & 0.986218 & \multicolumn{3}{|c|}{} \\
\hline
\end{tabular}

Source: $w w w . n s e i n d i a . c o m$ 
Table 8 shows the findings of the Regression Analysis for the PSU Bank Index. The study reveals that in June, September, November, December and February the adverse coefficient was observed, while the remaining months the adverse coefficient value was observed. At a risk level of 5 percent in July the coefficient was high and statistically important. The analysis considered all of the coefficients to be minor. R squared was negative of -0.0471 and the statistical significance of Durbin- Watson was less than two serial correspondences. It revealed that the returns for various months were distinct. The null hypothesis is thus accepted.

\section{CONCLUSION}

The research analyzed the impact in April of the indices of the Indian financial sector including, for example, the NIFTY BANK, NIFTY FINANCIAL SERVICES, the NIFTY PRIVATE BANK and the NIFTY PSU BANK NSE. It was observed that the April Month Impact influenced the daily prices of the entire Indian sample financial market. Simultaneously, each fiscal year's April month reported an adverse impact on most months of the same year. Thus, during investing in the stock market the investors should take into account the April month impact.

\section{REFERENCES}

[1] Gupta, G. (2017). Anomalies In The Indian Stock Markets: The December Effect. Journal Of Services Research, 17(1).

[2] Sahoo, R. (2018). Reaction Of Indian Stock Market During Weekend: An Empirical Study. International Journal Of Institutional \& Industrial Research, 3(1), 37-42.

[3] Harshita, Singh, S., \& Yadav, S. S. (2019). Unique Calendar Effects In The Indian Stock Market: Evidence And Explanations. Journal Of Emerging Market Finance, 18(1_Suppl), S35-S58.

[4] Tripathy, A., \& Leepsa, N. M. (2018). Seasonality In Indian Stock Market: Delusion Or Reality. IIMS Journal Of Management Science, 9(1), 37-43.

[5] Grossi, J. C., \& Malaquias, R. F. (2019). Is The Effect The Same Every January? Seasonality And Brazilian Equity Fund Flows. Revista Contabilidade \& Finanças, (AHEAD).

[6] Kayacetin, V., \& Lekpek, S. (2016). Turn-Of-The-Month Effect: New Evidence From An Emerging Stock Market. Finance Research Letters, 18, 142-157.

[7] Sikarwar, T. S., Shrivastava, K., \& Jadon, P. (2020). Friday The 13th Effect On Indian Stock Market. International Journal Of Financial Engineering, 7(02), 2050010.

[8] Singh, S., \& Das, C. (2020). Calendar Anomalies In The Banking And It Index: The Indian Experience. Asian Economic And Financial Review, 10(4), 439-448.

[9] Anjum, S. (2020). Impact Of Market Anomalies On Stock Exchange: A Comparative Study Of KSE And PSX. Future Business Journal, 6(1), 1-11.

[10] Khanh, P., \& Dat, P. (2020). Efficient Market Hypothesis And Calendar Effects: Empirical Evidences From The Vietnam Stock Markets. Accounting, 6(5), 893-898.

[11] Ali, F., \& Ülkü, N. (2020). Weekday Seasonality Of Stock Returns: The Contrary Case Of China. Journal Of Asian Economics, 101201. 
[12] Eric Girardin \& Fatemeh Salimi Namin. (2019). The January Effect In The Foreign Exchange Market: Evidence For Seasonal Equity Carry Trades. Economic Modelling, 81, 422-439.

[13] Wasiuzzaman, S. (2018). Seasonality In The Saudi Stock Market: The Hajj Effect. The Quarterly Review Of Economics And Finance, 67, 273-281.

[14] Quayyoum, S., Khan, M. H., Shah, S. Z. A., Simonetti, B., \& Matarazzo, M. (2019). Seasonality In Crude Oil Returns. Soft Computing, 1-10.

[15] Parikh, A. (2009). The December Phenomenon: Month-Of-The-Year Effect In The Indian Stock Market. NSE News, January. 